\title{
The Effects of Diet, Physical Activity, and Social Support on Overweight and Obesity in Female Adolescents
}

\author{
Yeti Rahelli'), Agus Kristiyanto²), Bhisma Murti') \\ 1)Masters Program in Public Health, Universitas Sebelas Maret \\ 2)Study Program in Physical Health Education and Recreation, Universitas Sebelas Maret
}

\section{ABSTRACT}

Background: Obesity is reaching global epidemic proportions with a threefold increase from 1975-2016. The percentage of adolescents aged 12-19 years old who are obese has increased from $5 \%-21 \%$ in the same period. The SCT can determine dietary behavior and regular physical activity. Study shows that a healthy diet, regular activity and social support contribute to weight gain. This study aims to estimate the effect of diet, physical activity, social support on overweight girls.

Subjects and Method: This study was an observational analytic study with a cross sectional design. The sample size was 120 study subjects using stratified random sampling. Data analysis with path analysis using the Stata 14 program.

Results: Overweight/ obesity was directly reduced by healthy diet $(b=-3.62 ; 95 \% \mathrm{CI}=-$ 5.08 to $-2.15 ; \mathrm{p}<0.001)$, healthy behavior $(\mathrm{b}=-$ 2.02; $95 \% \mathrm{CI}=-3.40$ to $-0.67 ; \mathrm{p}=0.003)$, and high physical activity $(b=-1.74 ; 95 \% \mathrm{CI}=-3.40$ to $-0.10 ; p=0.038$ ). Overweight/ obesity was indirectly affected by vicarious learning, maternal education, family income, and family support.

Conclusion: Overweight/ obesity is directly reduced by healthy diet, healthy behavior, and high physical activity. Overweight/ obesity is indirectly affected by vicarious learning, maternal education, family income, and family support

Keywords: diet, physical activity, family support, SCT, path analysis

\section{Correspondence:}

Yeti Rahelli. Master of Public Health Sciences, Universitas Sebelas Maret. Jl. Ir. Sutami No. 36A Kentingan Surakarta 57126, Central Java, Indonesia. Email: yetirahelli@student.uns.ac.id

Cite this as:

Rahelli Y, Kristiyanto A, Murti B (2020). The Effects of Diet, Physical Activity, and Social Support on Overweight and Obesity in Female Adolescents. J Health Promote Behav. 05(03): 209-218. https://doi.org/10.26911/thejhpb.2020.05.03.07.

cc (i) (-) Journal of Health Promotion and Behavioris licensed under a Creative Commons Attribution-NonCommercial-ShareAlike 4.o International License.

\section{BACKGROUND}

Obesity has increase by 4 times in adolescence in the last 30 years. The percentage of adolescents aged 12-19 who are obese increased from $5 \%$ to $21 \%$ in the $1975-2016$ period. Based on UNICEF in 2018 as many as $15 \%$ of adolescents in Indonesia are overweight or obese.

Currently, Indonesia has 3 major health problems, namely stunting, wasting and obesity. Based on the Basic Health Rises (Riskesdas) of Yogyakarta Province in
2013, it shows the prevalence of overweight is $12.9 \%$ and obesity is $6 \%$ in adolescents aged 16-18 years in Yogyakarta City. Based on a UNICEF survey in 2018, it was found that there were changes in diet and physical activity in adolescents that led to overweight and obesity.

Increased BMI in adolescents is a major risk factor for non-communicable diseases such as cardiovascular disease, diabetes, musculoskeletal disorders, and several cancers such as endometrial, breast, 
ovarian, kidney and colon cancer. Overweight and obesity can mostly be prevented. A supportive environment and society determines one's choices, such as in choosing healthier food consumption and regular physical activity (WHO, 2020).

\section{SUBJECTS AND METHOD}

\section{Study Design}

This was an analytic observational study with a cross sectional design. The study was conducted at 4 islamic senior high school in Yogyakarta.

\section{Population and Sample}

The population in this study were female adolescents. A sample of 120 female adolescents was selected by stratified random sampling.

\section{Study Variables}

The dependent variable is overweight/ obesity. The independent variables are maternal education, family income, diet, physical activity, social support (family support), and SCT (vicarious learning and behavior) variables.

\section{Definition of Operational Variables}

The body weight of the study subjects $(\mathrm{kg})$ at the time of data collection obtained by filling out a questionnaire sheet, then divided by the height squared (m), the results of the next calculation used a special percentile for age and gender to determine the weight status of the research subject. The body weight is more if the percentile is $\geq 85^{\text {th. }}$

Maternal education is the last formal education level taken by the parents of the study subject.

Family income is the income received by parents from working in the last 6 months is calculated on average per month with nominal rupiah in order to meet the daily needs of life that affect children's food intake.
Diet is food diet consumed by study subjects to control, control, or lose weight so that there is no overweight and even obsession.

Physical activity is an activity carried out by study subjects to make the body condition improve health and maintain physical health.

Family support is support from parents or siblings in the form of helping or giving physical/psychological attention to study subjects to control or lose weight so that overweight and obesity do not occur.

Vicarious learning is behavioral learning through observation or observation of other people's behavior, especially a leader or someone who is considered to have more value than himself who will later become a vicarious experience.

Behavior is the formation of a new, healthy behavior after learning through observation or imitation (modeling).

Data Collection Tools: Questionnaires that have been tested for validity and reliability. Measuring scale: Continuous data. For the purposes of data analysis, continous data is converted into dichotomous data.

\section{Data Analysis}

Univariate analysis was used to describe each dependent and independent variable. Bivariate analysis (chi square) was used to explain the relationship between one independent variable and the dependent variable. Path analysis was used to determine the influence of an independent variable on the dependent variable, either directly or indirectly.

\section{Study Ethics}

This study has received ethical eligibility from the Health Research Ethics Commission of Dr. Moewardi Hospital Number: 1.138/IX/HREC/2020 and carried out by upholding and applying the principles of research ethics, namely respect for person, 
Rahelli et al./ The Effects of Diet, Physical Activity, and Social Support on Overweight and Obesity

beneficence and non-maleficence, and justice.

\section{RESULTS}

\section{Sample Characteristics}

Total study subjects in this study were 120 female adolescents in HS/MAN in Yogyakarta City. Most of the body weight status was in the normal weight category, which was 66 (55.00\%) study subjects, while the least obesity category was 9 (7.5\%) study subjects. The most recent education of fathers graduated from tertiary education, which was 54 (45\%) and at least graduated from elementary school, which was 1 (o.83\%) study subject.

Table 1. Distribution of Characteristics of Study Subjects (Continuous Data)

\begin{tabular}{lccccc}
\hline Characteristics & n & Mean & SD & Min. & Max. \\
\hline Age & 120 & 17.15 & 1.120 & 15 & 19 \\
Body Weight & 120 & 53.004 & 11.133 & 36 & 85 \\
Body Height & 120 & 156.183 & 5.321 & 138 & 172 \\
\hline
\end{tabular}

Table 1showed that the results of the measurement of the age characteristics of the study subjects have a mean $=17.15, \mathrm{SD}=1.12$, the lowest age was 15 years old, and the highest age was 19 years old. The body weight of the study subjects had a mean value of $53,004, \mathrm{SD}=11,133$, the lowest body weight
Most of the mothers' last education graduated from college which was 49 (40.83\%) and at least graduated from ES was $2(1.67 \%)$ study subjects. Most of the father's income ranges from $>\mathrm{Rp} 1,000,000$ to $\operatorname{Rp} 4,000,000$, that was 58 (48.33\%), while the least amount was in the range of $o$ to. IDR 1,000,000, that was 19 (15.83\%) study subjects.

Maternal income was mostly in the range $\mathrm{O}$ to $\mathrm{Rp} 1,000,000$, namely 69 (57.5\%), while the least amount was in the range of $>\operatorname{Rp} 4,000,000$ to $\mathrm{Rp} 7,000,000$, which was 4 (3.33\%) study subjects.

\begin{tabular}{lcc}
\multicolumn{1}{c}{ Table2.Distribution of Diet, } & Physical Activity, Family Support, & Peer Support \\
\hline \multicolumn{1}{c}{ Variables } & Total (f) & Percentage (\%) \\
\hline Not healthy & 25 & 20.83 \\
$\quad$ Healthy & 95 & 79.17 \\
Physical Activity & & \\
$\quad$ Less & 18 & 15 \\
$\quad$ A lot & 102 & 85 \\
Family Support & & \\
Not supportive & 28 & 23.33 \\
Supportive & 92 & 76.67 \\
\hline
\end{tabular}

Table 2 showed that most of the study subjects did a healthy diet by 95 (79.17\%) and the least did an unhealthy diet by 25 (20.83\%). The physical activity category was mostly in the large category, which was was $36 \mathrm{~kg}$ and the highest body weight was 85 $\mathrm{kg}$.

The characteristics of the height of the study subjects had a mean value of 156,183 , $\mathrm{SD}=5,321$, the shortest study subjects was $138 \mathrm{~cm}$ and the highest was $172 \mathrm{~cm}$. 92

$102(85 \%)$ and less was 18 (15\%). Most of the family support categories were study subjects with supportive families, which was 92 (76.67\%) and 28 unsupportive families (23.33\%). 
Table 3. Distribution of Social Cognitive Theory Variables

\begin{tabular}{lccccc}
\hline \multicolumn{1}{c}{ Variable } & $\mathbf{n}$ & Mean & SD & Min. & Max. \\
\hline Vicarious Learning & 120 & 0.80 & 0.395 & 0 & 1 \\
Behavior & 120 & 0.65 & 0.478 & 0 & 1 \\
\hline
\end{tabular}

Based on table 3 , the vicarious learning variable has a mean $=0.80$ and $\mathrm{SD}$ 0.395 , the lowest value for vicarious learning variable was 0 and the highest was 1.

\section{Results of bivariate analysis}

Table 4. Bivariate Analysis of the Effect of Diet, Physical Activity, Social Support and Social Cognitive Theory on Overweight

\begin{tabular}{|c|c|c|c|c|c|c|c|c|}
\hline \multirow{2}{*}{$\begin{array}{l}\text { Independent } \\
\text { Variables }\end{array}$} & \multicolumn{2}{|c|}{$\begin{array}{c}\text { Percentile } \\
<85\end{array}$} & \multicolumn{2}{|c|}{$\begin{array}{c}\text { Percentile } \\
\geq 85\end{array}$} & \multirow[t]{2}{*}{ OR } & \multicolumn{2}{|c|}{$95 \% \mathrm{CI}$} & \multirow[b]{2}{*}{$\mathbf{p}$} \\
\hline & $\mathbf{n}$ & $\%$ & $\mathbf{n}$ & $\%$ & & $\begin{array}{c}\text { Lower } \\
\text { Limit }\end{array}$ & $\begin{array}{l}\text { Upper } \\
\text { Limit }\end{array}$ & \\
\hline \multicolumn{9}{|l|}{ Maternal Education } \\
\hline Low & 12 & 37.50 & 20 & 62.50 & 0.15 & 0.05 & 0.40 & $<0.001$ \\
\hline High & 71 & 80.68 & 17 & 19.32 & & & & \\
\hline \multicolumn{9}{|l|}{ Family Income } \\
\hline Low & 23 & 48.94 & 24 & 51.06 & 0.21 & 0.08 & 0.51 & $<0.001$ \\
\hline High & 60 & 82.19 & 13 & 17.81 & & & & \\
\hline \multicolumn{9}{|l|}{ Diet } \\
\hline Unhealthy & 4 & 16.00 & 21 & 84.00 & 0.04 & 0.01 & 0.14 & $<0.001$ \\
\hline Healthy & 79 & 83.16 & 16 & 16.84 & & & & \\
\hline \multicolumn{9}{|l|}{ Physical Activity } \\
\hline Less & 3 & 16.67 & 15 & $83 \cdot 33$ & 0.06 & 0.01 & 0.30 & $<0.001$ \\
\hline A lot & 80 & 78.43 & 22 & 21.57 & & & & \\
\hline \multicolumn{9}{|l|}{ Family Support } \\
\hline Not supportive & 10 & 35.71 & 18 & 64.29 & 0.15 & 0.05 & 0.47 & $<0.001$ \\
\hline Supportive & 73 & 79.35 & 19 & 20.65 & & & & \\
\hline \multicolumn{9}{|l|}{ Vicarious Learning } \\
\hline Low & 6 & 26.09 & 17 & 73.91 & 0.11 & 0.03 & 0.30 & $<0.001$ \\
\hline High & 77 & 79.38 & 20 & 20.62 & & & & \\
\hline \multicolumn{9}{|l|}{ Behavior } \\
\hline Unhealthy & 16 & 38.10 & 26 & 61.90 & 0.10 & 0.04 & 0.32 & $<0.001$ \\
\hline Healthy & 67 & 85.90 & 11 & 14.10 & & & & \\
\hline
\end{tabular}

\section{Results of Path Analysis}

Table 5 shows the indirect effect of parental education on overweight/ obesity through physical activity, female adolescents with high parental education were 1.82 unit more likely to do physical activity than those with low parental education $(b=1.82$; 95\% $\mathrm{CI}=0.60$ to $2.99 ; \mathrm{p}=0.003)$. Parental education has an indirect effect on overweight/obesity through diet and was
Variable of behavior has a mean $=0.65$ and SD 0.478 , the lowest value for the behavior variable was 0 and the highest was 1 . 
engage in healthy behaviors than those with low parental education $(b=1.53 ; 95 \% \mathrm{CI}=$ 0.58 to $2.50 ; p=0.002$ ).

Family income has an indirect effect on overweight/obesity through family support, it mean that female adolescents with high family income have a 1.21 unit higher probability of getting support from family than those with low family income $(b=1.21 ; 95 \% \mathrm{CI}=0.29$ to $2.03 ; \mathrm{p}=0.009)$.

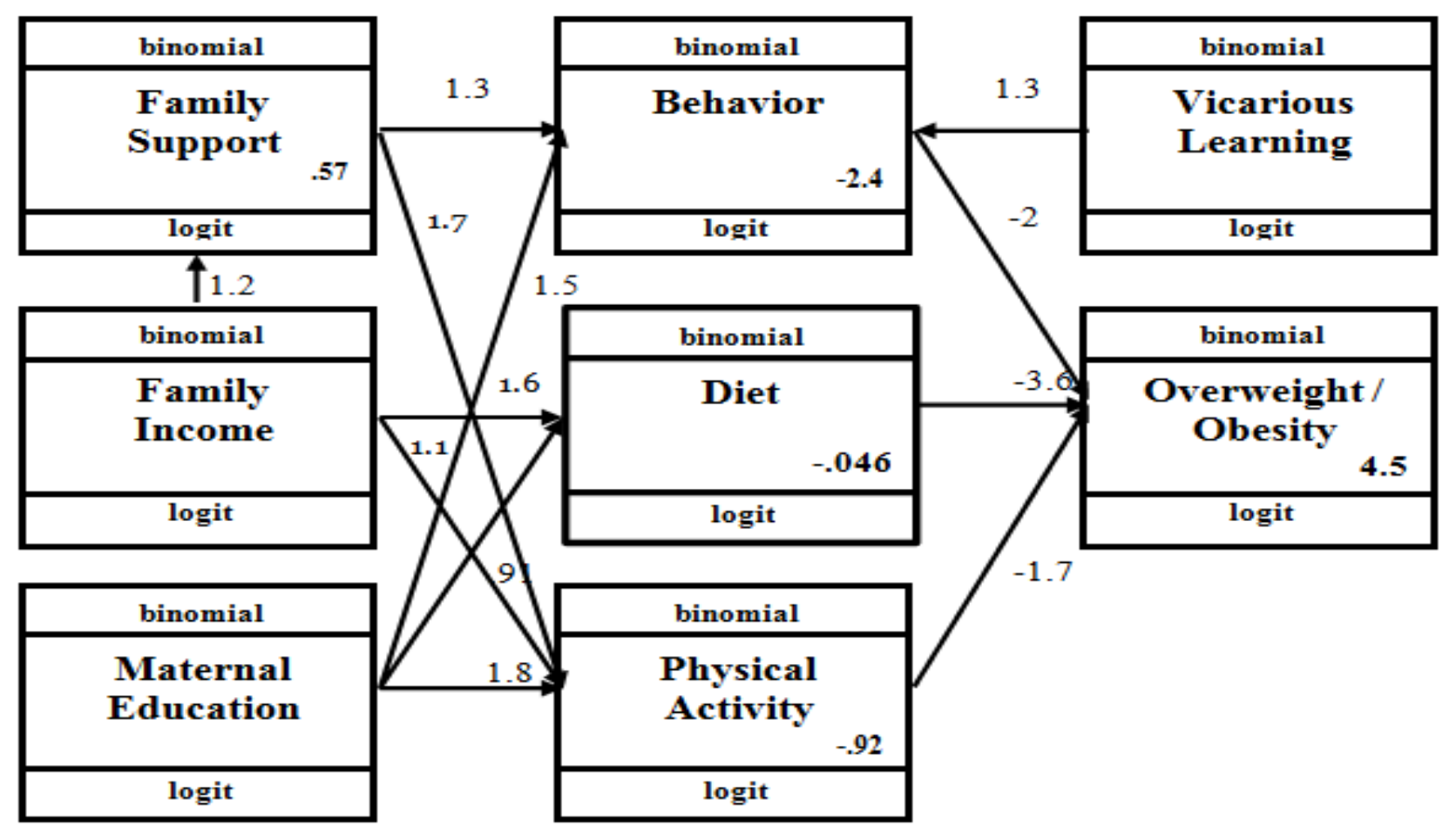

Figure 1. Structural Model Estimation

Table 5.Path analysis of the influence of diet, physical activity and social support on overweight and obesity in female adolescents

\begin{tabular}{|c|c|c|c|c|c|c|}
\hline \multirow{2}{*}{$\begin{array}{l}\text { Dependent } \\
\text { Variables }\end{array}$} & \multirow{2}{*}{\multicolumn{2}{|c|}{$\begin{array}{l}\text { Independent } \\
\text { variables }\end{array}$}} & \multirow{2}{*}{$\begin{array}{c}\text { Path } \\
\text { Coef. (b) }\end{array}$} & \multicolumn{2}{|c|}{$95 \% \mathrm{CI}$} & \multirow[b]{2}{*}{$\mathbf{p}$} \\
\hline & & & & $\begin{array}{l}\text { Lower } \\
\text { Limit }\end{array}$ & $\begin{array}{l}\text { Upper } \\
\text { Limit }\end{array}$ & \\
\hline \multicolumn{7}{|l|}{ Direct Effect } \\
\hline \multirow{3}{*}{ Overweight/Obesity } & & Diet (healthy) & -3.62 & -5.08 & -2.15 & $<0.001$ \\
\hline & $\leftarrow$ & Behavior (healthy) & -2.02 & -3.40 & -0.67 & 0.003 \\
\hline & & PhysicalActivity (a lot) & -1.74 & -3.40 & -0.10 & 0.038 \\
\hline \multicolumn{7}{|l|}{ Indirect Effect } \\
\hline Physical Activity & & Maternal Education (high) & 1.82 & 0.60 & 2.99 & 0.003 \\
\hline Diet & $\leftarrow$ & Maternal Education (high) & 1.00 & -0.08 & 0.77 & 0.070 \\
\hline Behavior & $\leftarrow$ & Maternal Education (high) & 1.53 & 0.58 & 2.50 & 0.002 \\
\hline Family Support & $\leftarrow$ & Family Income (high) & 1.21 & 0.29 & 2.03 & 0.009 \\
\hline Diet & $\leftarrow$ & Family Income (high) & 1.63 & 0.62 & 2.63 & 0.002 \\
\hline Physical Activity & $\leftarrow$ & Family Income (high) & 1.22 & -0.12 & 2.35 & 0.077 \\
\hline Behavior & $\leftarrow$ & Family Support (supportive) & 1.37 & 0.18 & 2.34 & 0.023 \\
\hline Physical Activity & & Family Support (supportive) & 1.73 & 0.56 & 2.93 & 0.004 \\
\hline Behavior & $\leftarrow$ & Vicarious Learning (high) & 1.37 & 0.06 & 2.45 & 0.039 \\
\hline
\end{tabular}

Family income has an indirect effect on overweight/obesity through diet, female adolescents with high family income have a 1.63 unit higher chance of having a healthy 
diet than those with low family income $(\mathrm{b}=$ 1.63; 95\% CI= 0.62 to $2.63 ; \mathrm{p}=0.002$ ).

Family income has an indirect effect on overweight/obesity through physical activity and it was nearly statistically significant, female adolescents with high family income have a 1.22 unit higher likelihood of doing physical activity more than those with low family income $(b=1.22 ; 95 \% \mathrm{CI}=-$ 0.12 to $2.35 ; \mathrm{p}=0.077$ ).

Family support has an indirect effect on overweight/obesity through behavior, female adolescent with supportive families have a 1.37 unit higher likelihood of engaging in healthy behaviors than those with unsupportive families $(b=1.37 ; 95 \%$ $\mathrm{CI}=0.18$ to $2.34 ; \mathrm{p}=0.023$ ).

Family support has an indirect effect on overweight/obesity through physical activity, female adolescents with supportive families were 1.73 unit more likely to do more physical activity than those with unsupportive families $(b=1.73 ; 95 \% \mathrm{CI}=$ 0.56 to $2.93 ; \mathrm{p}=0.004)$.

Vicarious learning has an indirect effect on overweight/obesity through behavior, female adolescents with high vicarious learning have a 1.37 unit higher likelihood of behaving healthy than those with low vicarious learning $(\mathrm{b}=1.37 ; 95 \% \mathrm{CI}=0.06$ to $2.45 ; \mathrm{p}=0.039$ ).

Diet has a direct effect on overweight/ obesity in female adolescent. Female adolescents who do a healthy diet have a 3.62 unit lower likelihood of experiencing overweight/obesity than those with an unhealthy diet $(b=-3.62 ; 95 \% \mathrm{CI}=-5.08$ to $-2.15 ; \mathrm{p}<0.001)$.

Behavior has a direct effect on overweight/obesity in female adolescents. Female adolescents with healthy behavior have a 2.02 unit lower chance of experiencing overweight/obesity than those with unhealthy behavior $(\mathrm{b}=-2.02 ; 95 \% \mathrm{CI}=$ 3.40 to $-0.67 ; \mathrm{p}=0.003$ ).
Physical activity has a direct effect on overweight/obesity in female adolescent. Female adolescents who do a lot of physical activity have a 1.74 unit lower likelihood of experiencing overweight/obesity than those with lack of physical activity $(b=-1.74 ; 95 \%$ $\mathrm{CI}=-3.40$ to $-0.10 ; \mathrm{p}=0.038$ ).

\section{DISCUSSION}

There was an indirect effect of parental education on overweight/obesity through physical activity. A similar study by Haya (2016) shows a positive effect of parental education on physical activity levels ( $p=$ o.001). Parents with a high level of education will understand how to maintain health better, so that the ways to maintain health can be delivered to their children such as active physical activity. This is in contrary from parents whose educational level is low, their knowledge will also be low. Similar research by Pavon (2012) shows that there is a significant effect between parental education and physical activity on children's physical activity.

There was an indirect effect of parental education on overweight/obesity through diet. A similar study by Handayani (2019) shows that there was a significant relationship between parental knowledge and dietary adherence $(\mathrm{p}=0.004)$. Education is a determining factor for a person's knowledge and attitudes. The higher the formal education that parents take, the higher their mindset and ability to absorb information about their own health (Handayani, 2019). Parental education can help reduce energy intake for children's daily food needs (Haya, 2016). The more information the parents get, the more motivation and skills they will get, so that more attitudes are formed (Amir, 2018).

There was an indirect effect of parental education on overweight/obesity through behavior. Similar by Finders (2016) states 
that high parental education supports healthy children's behavior. According to Handayani in 2019, the determining factor in the attitude and knowledge that parents have is the last formal education taken by parents. Social Cognitive Theory explains that a person's personality develops through a process of observation. A person can learn through observation or observation of the behavior of other people, especially a leader or someone who is considered to have more value for himself (Bandura, 1986). Learning in this case is healthy behavior carried out by parents to be emulated by their children.

There was an indirect effect of parents' income on overweight/obesity through family support. Mireku (2020) shows that the risk of overweight and obesity in adolescents increases along with decreasing family income $(\mathrm{p}=0.001)$. The relationship between parents and children is an important factor in forming emotional bonds (James, 2018). High income allows parents to provide full support to their children such as instrumental, emotional, informational, and rewarding support. A supportive environment such as the presence of parents can increase weight loss efforts (Hansen, 2018).

There was an effect of family income on overweight/obesity through diet. Similar research by Noonan (2018) shows the results that adolescents in the low income group have a risk of being overweight and obese. In general, the economic status of the family is closely related to the last education taken by parents (Arnold, 2018). Diet plays an important role in children's growth and development, but children's food intake is influenced by household income (Shariff, 2015). Research conducted by Gilliland in 2015 shows that adolescents from high-income families have an intake of unsaturated fats, meet recommendations for dairy products, fruits, and vegetables compared to adolescents with low parental income.

There was an indirect effect of family income on overweight/obesity through physical activity. A similar study by Kim (2014) shows that there was an effect of family income on physical activity and it was statistically significant $(\mathrm{p}<0.001)$. A study by Jin (2015) shows that the prevalence of obesity of $20.3 \%$ and $56 \%$ of children classified as having low family income is associated with low fitness scores/low physical activity. A similar study by Duan (2019) shows that family income can be a good approach to children through attitude taken by parents such as healthy lifestyle changes and not buying certain foods that are considered unhealthy. Low family income can be a barrier to physical activity and consumption of healthy foods (Hanson, 2017).

There was an effect of family support on overweight/obesity through behavior. Behavior change can be done by presenting the role of parents or close family as a component of the intervention (Ganster, 2012). In line with the concept of reciprocal determinism, parents can influence children's behavior through changes in the physical or social environment. For example, parents influence a child's diet by controlling food availability, making healthy foods, and making meal schedules (Miller, 2017). Parents' behavior will be imitated by children and will form new skills around health behavior (Dwyer, 2017).

There was an indirect effect of family support on overweight/obesity through physical activity. This study is similar to a study by Morrissey (2015), showing that there is an effect of family support on increasing physical activity of adolescents aged 13-17 years. Providing this support can make children more valued, confident, and 
motivated to change behaviors such as healthy eating patterns and active physical activity (Warnick, 2019). Parental support provided to children in behavior change is also carried out with health education, consumption of unhealthy fast food, and the importance of exercising fitness with physical activity (Marie, 2018). Social Cognitive Theory can be an initiative in changing health and physical activity through the environment (Marie, 2018). The literature shows that parental behavior can influence children's knowledge about health, selfefficacy, and expected outcomes. This is a learning process from parents to children, the process is learn by observing the environment as a means of obtaining knowledge, information, and changing behavior.

There was an indirect effect of vicarious learning on overweight/obesity through behavior. Social Cognitive Theory explains that a person's personality develops through a process of observation. Individuals can learn through observation or observation of other people's behavior, especially leaders or someone who is considered to have more value than themselves (Bandura, 2001). Similar study by Knol (2017) shows that positive/healthy behavior in maintaining a healthy lifestyle increases after intervention from the child's social environment. According to Bandura (1986) adults, symbolic models of television/ movie, and visual media play an important role in the formation of attitudes and behavior. This imitation or modeling is not only mimicking or repeating role modeling behaviors, but also involves adding or subtracting observed behavior, generalizing various observations as well as involving cognitive processes (Bandura, 1967).

There was a direct effect of diet on overweight/obesity in female adolescent. A healthy diet such as consuming balanced nutritious foods and not skipping meals can make the body's metabolism run smoothly, so that it can maintain or lose ideal body weight, and vice versa, an unhealthy diet will only lead to overweight/obesity (Almuhana, 2014). Similar study by Heryuditasari (2018) shows that there is a significant effect of diet on obesity. Female adolescents with unhealthy diets such as skipping meals, consuming high-calorie foods, fast food, and rarely consuming vegetables and fruits are certainly more at risk of experiencing overweight or obesity than young women who are on a healthy diet (Mekonnen, 2018). The main focus in maintaining ideal body weight is behavior modification (Wilfley, 2019). Social Cognitive Theory plays a role in changing adolescent diet behavior, namely the interaction of environmental factors such as family function, then cognitive factors such as expectations of results, and adolescent behavior. This theory is seen as successful in weight loss programs in various observational studies based on family environments (Bagherniya, 2018).

There was a direct effect of behavior on overweight/obesity in female adolescent. Kheng (2019) states that healthy behavior can be formed through the roles and functions of parents. These roles and functions include health education regarding nutrition, physical activity, positive parenting skills, parental behavior, and children's behavior management to encourage healthy eating/exercise behavior. Social Cognitive Theory is considered to have succeeded in preventing or controlling obesity, because there are social and cognitive factors in explaining individual behavior. Positive belief in behavior will certainly have a positive influence on healthy behavior (James, 2018). Environmental factors will affect children's cognitive factors such as self-efficacy and outcome expectations (Marie, 2018). Children will certainly have more 
Rahelli et al./ The Effects of Diet, Physical Activity, and Social Support on Overweight and Obesity

self-confidence after being given reinforcement or motivation by their parents, so that children will try to change their behavior.

There was a direct effect of physical activity on overweight/obesity in female adolescent. This study was in line with Utami (2017), which shows the influence of adolescent physical activity on the incidence of overweight or obesity. Inactive/ lack of physical activity in adolescents is related to sedentary lifestyle such as watching television, playing mobile phones, and excessive gaming. Robinson (2017) states that obesity in children and adolescents can be caused by prolonged exposure to screen media through increased eating while watching, the presence of high-calorie and low nutrition food and drink advertisements, and unhealthy eating patterns. Social Cognitive Theory is the an effective theory for changing physical activity behavior (Taylor, 2016). This theory explains the predictors and principles of behavior change using constructs such as self-efficacy, outcome expectations, and environmental factors such as family or friends (Shamizadeh, 2019). A study by Pojskic (2018) shows the importance of the role of the environment, especially schools for physical activity, regardless of whether or not children are obese, because high physical activity improves physical fitness and reduce the risk of obesity.

\section{AUTHOR CONTRIBUTION}

Research topics/concepts: Yeti Rahelli, Agus Kristiyanto, Bhisma Murti

Data Analysis: Yeti Rahelli, Bhisma Murti

Original Manuscript: Yeti Rahelli

Review, Editing: Yeti Rahelli, Agus Kristiyanto, Bhisma Murti

\section{CONFLICT OF INTEREST}

There was no conflict of interest in this study.

\section{FUNDING AND SPONSORSHIP}

None.

\section{ACKNOWLEDGEIMIENT}

This research has been approved for its truth and authenticity based on novelty by the authors, supervisors and agencies in its implementation and preparation.

Almuhanna MA, Alsaif M, Alsaadi M
(2014). Fast food intake and prevalence of obesity in school children in riyadh city. Sudan J Paed. 14(1):7180. https://www.ncbi.nlm.nih.gov/pubmed/27493393.

Amirudin MM, Faridha N (2014). Hubungan antara pendapatan orang tua dengan status gizi pada siswa SDN II Tenggarong Rejotangan Tulungagung (The relationship between parents' income and nutritional status in students of SDN II Tenggarong Rejotangan Tulungagung). Surabaya: Universitas Negeri Surabaya.

Arnold LS, Andreas B (2018). The effects of relationship education in low-income couples: a meta-analysis of randomized-controlled evaluation studies. Fam Relat. 68(1):22-38. https://doi.org/10.1111/fare.12325.

Bagherniya M, Mostavi DF, Sharma M (2018). Assessment of the efficacy of physical activity level and lifestyle behavior interventions applying social cognitive Theory for overweight and obese girl adolescent. J Res Health Sci. 18(2):1-8. PMID: 29784890.

Bandura A (1986). Social foundations of thought and action: a social-cognitive theory. United States of America: Prentice Hall. 
Rahelli et al./ The Effects of Diet, Physical Activity, and Social Support on Overweight and Obesity

Bandura A (1997). Self efficacy, the exercise of control. New York: W.H. Freeman and Company.

Bandura A (2001). Social cognitive theory: an agentic perspective. Annu Rev Psychol. 52(1):1-26.

Chen W, Hammond BA, Hypnar A, Mason $S$ (2018). Health related physical fitness and physical activity in elementary school students. BMC Public Health. 18(4):195. https://doi.org/10.1186/s12889-018-5107-4.

Duan JZ, Bery E, Helena HL (2019). Diet and physical activity changes among low-income families: perspective of mother and their children. Int J Qual Stud Heal. 14(1):2-15. https://dx.doi.org/10.1080\%2F17482631.2019.1658 700.

Dwyer B, Shapiro SL, Drayer J (2017). Daily fantasy football and self-reported problem behavior in the United States. J Gambl Stud. 3(2):1-2. https://doi.org/10.1007/s10899-017-9720-4.

Finders JK, Guadalupe D, Geldhof GJ (2016). The impact of parenting education on parent and child behaviors: Moderators by income and ethnicity. Child Youth Serv Rev. 71(11): 199-209. https://doi.org/10.1016/j.childyouth. 2016.11.006.

Ganster DC, Fusilier MR, Mayes BT (2012). Role of social support in the experience of stress at work. J Appl Psychol. 71(1):102-10. https://psycnet.apa.org/doi/10.1037/o021-9010.71.1.102.

Gilliland FD, Bin X (2015). Effects of ethnicity, family income, and education on dietary intake among adolescent. Prev Med. 36(1):30-40. https://doi.org/10.1006/pmed.2002.1131.

Handayani P, Mazarina D, Agung K (2019). Hubungan pengetahuan gizi orang tua dan pendapatan orang tua dengan kepatuhan orang tua dalam penerapan diet autis pada anak autis di SLB autis laboratorium UNM (The relationship between parental nutritional knowledge and parental income with parental compliance in the application of the autistic diet to autistic children in special schools autism UNM laboratory). Preventia. 4(1):1-8.

Hansen S, Huttunen-Lenz M, Sluik D (2018). Demographic and social cognitive factors associated with weight in overweight, pre-diabetic participants of the preview study. Int $\mathrm{J}$ Behav Med. 25(6):682-692. https://dx.doi.org/10.1007\%2Fs12529-018-9744-X.

Haya M, Maria M, Margawati A (2016). Effect of maternal health education on physical activity and body mass index of overweight children. Paediatr Indones. 56(2):73-77. https://doi.org/10.14238/pi56.2.2016.73-8.

Heryuditasari (2018). Hubungan pola makan dengan kejadian obesitas (studi di SMK Bakti Indonesia Medika Jombang (The relationship between diet and obesity (study at SMK Bakti Indonesia Medika Jombang). Jombang: Sekolah Tinggi Ilmu Kesehatan Insan Cendekia Medika.

James PR, Pramodita S, Alfredo DM (2018). Perceived parental behaviors and next-generation engagement in family firms: a social cognitive perspective. Sage Res Pap Soc Sci. 43(2): 1-5. https://doi.org/10.1177\%2F1042258718796087.

Jin Y, Jessica CJM (2015). Associations between family income and children's physical fitness and obesity in California, 2010-2012. Prev Chronic Dis. 12(17):1-9. http://dx.doi.org/10.5888/pcd12.140392. 
Rahelli et al./ The Effects of Diet, Physical Activity, and Social Support on Overweight and Obesity

Kim IG, Wi YS (2014). The relationship between household income and physical activity in Korea. J Phys Ther Sci. 26(12):1887-1889. https://dx.doi.org/10.1589\%2Fjpts.26.1887.

Knol LL, Harriet HM, Sheila B (2017). Development and feasibility of a childhood obesity prevention program for rural families: application of the social cognitive theory. Am J Health Educ. 47(4): 204-214. https://dx.doi.org/10.1080\%2F19325037.2016.1179 607.

Marie L (2018). Applying social cognitive theory in an naturopathy healthcare educational program for parents and families. Arch Gen Intern Med. 2(1):32-36.

Mekonnen T, Tariku A, Abebe SM (2018). Overweight/obesity among school aged children in Bahir Dar City: cross sectional study. Ital J Pediatr. 44(17): 1-8. https://dx.doi.org/10.1186\%2Fs13052-018-0452-6.

Miller J, Leslie E (2017). Relationship between the home environment and fruit and vegetable consumption in children aged 6-12 years: a systematic review. Public Health Nutr. 20(3): 464-480. https://doi.org/10.1017/s1368980016002883.

Mireku MO, Alina R (2020). Family income gradients in adolescent obesity, overweight and adiposity perist in extremely deprived and extremely affluent neighbourhoods but not in middleclass neighbourhoods: evidence from the UK millenium cohort study. Int J Env Res Pub He. 17(2):418. https://doi.org/10.339o/ijerph17020418.

Morrissey JL, Kathleen FJ, Elena ML (2015). The effect of family and friend support on physical activity through adolescence: a longitudinal study. Int J Behav Nutr Phys Act. 12(103):1-9. https://doi.org/10.1186/s12966-0150265-6.

Noonan RJ (2018). Poverty, weight status, and dietary intake among UK adolescents. Int $\mathrm{J}$ Environ Res Pubic Health. 15(6):1224. https://doi.org/10.3390/ijerph15061224.

Pavon DJ, Juan MFA, Saskia JV (2012). Associations of parental education and parental physical activity (PA) with children's PA: the energy crosssectional study. Prev Med. 55(2):310314 .

Pojskic H, Bahareh E (2018). Relationship between obesity, physical activity, and cardiorespiratory fitness levels children and adolescents in Bosnia and Herzegovina: An analysis of gender differences. Front Physiol. 9(1734):112. https://doi.org/10.3389/fphys.2018.01734 .

Shamizadeh T, Leila J, Parvin S, Koen P (2019). Social cognitive theory-based intervention to promote physical activity among prediabetic rural people: a cluster randomized controlled trial. Trials. 20(98):1-10. https://doi.org/10.1186/s13063-019-3220-Z.

Shariff ZM, Khor GL, Sarina S, Huang SL (2015). The relationship between household income and dietary intakes of 1-10 year old urban Malaysian. Nutr Res Pract. 9(3):278-287. https://dx.doi.org/10.4162\%2Fnrp.2015.9.3 .278 .

Taylor LM, Raine KD, Plotnikoff (2016). Understanding physical activity in individuals with prediabetic: an application of social cognitive theory. Psychol Health Med. 21(2): 254-60. https://doi.org/10.1080/13548506.2 015.1058486.

UNICEF (2018). Nutrition: talking the double burden of malnutrition in 
Rahelli et al./ The Effects of Diet, Physical Activity, and Social Support on Overweight and Obesity

Indonesia. New York: United Nations Children's Fund.

Warnick JL, Sarah ES, Kendra MK, David MJ (2019). Family functioning mediates the relationship between child behavior problems and parent feeding practices in youth with overweight or obesity. Transl Behav Med. 9(3):431439. https://doi.org/10.1093/tbm/ibzO5O.

WHO (2020). Coming of age: adolescent health. Geneva: World Health Organization.
WHO (2020). Healthy diet. Geneva: World Health Organzation.

Wilfley DE, Jacqueline FH, Katherine NB (2019). Behavioral interventions for obesity in children and adults: evidence-base, novel approaches, and translation into practice. Am Psychol. 73(8):981-993. https://doi.org/10.1037/ampoooo293. 